\title{
Tensegrity: Construction of Rigid DNA Triangles with Flexible 4-Arm DNA Junctions
}

Dage Liu, Mingsheng Wang, Zhaoxiang Deng, Richard Walulu, Chengde Mao*

Department of Chemistry, Purdue University, West Lafayette, Indiana 47907

\section{Supporting information}

\section{Materials and Methods:}

DNA strands. All DNA oligomers were designed with computer program "Sequin" (N.C. Seeman, J. Biomol. Struct. Dyns. 8, 573 [1990]), purchased from the Integrated DNA Technology, Inc., and purified with denaturing polyacrylamide gel electrophoresis.

DNA self-assembly. DNA complexes were formed by mixing a stoichiometric quantity of each strand $(50 \mathrm{nM})$, as estimated by $\mathrm{OD}_{260}$, in TAE/ $\mathrm{Mg}^{2+}$ buffer (40 mM Tris-HCl, $20 \mathrm{mM}$ acetic acid, $2 \mathrm{mM}$ EDTA, and $12.5 \mathrm{mM}$ magnesium acetate, $\mathrm{pH} \mathrm{8.0)}$. The mixtures were cooled slowly from $90^{\circ} \mathrm{C}$ to $4^{\circ} \mathrm{C}$ in a 2 liter water bath. The cooling process took 4 hours for individual triangle and 1D arrays, 2 days for 2D arrays.

Native gel electrophoresis. Gels contained 8\% acrylamide (19:1, acrylamide:bisacrylamide) and TAE/ $\mathrm{Mg}^{2+}$ buffer. $1 \mu \mathrm{L}$ tracking dye containing TAE/ $\mathrm{Mg}^{2+}, 50 \%$ glycerol, and $0.2 \%$ each of Bromophenol Blue and Xylene Cyanol FF was added to each sample $(1.5 \mu \mathrm{g}$ DNA is in $10 \mu \mathrm{L}$ of $\left.\mathrm{TAE} / \mathrm{Mg}^{2+}\right)$. Gels were run on a Hoefer SE-600 electrophoresis unit at $4 \mathrm{~V} / \mathrm{cm}$ at room temperature and stained with Stains-all (0.01\% Stains-All from Sigma, 45\% formamide) and then scanned.

Thermal denaturation. DNA strands were dissolved to $1 \mu \mathrm{M}$ concentration in $1 \mathrm{~mL}$ of a solution containing $40 \mathrm{mM}$ sodium cacodylate, and $10 \mathrm{mM}$ magnesium acetate, $\mathrm{pH} 7.5$, and annealed as described above. The samples were transferred to quartz cuvettes, and the cacodylate buffer was used as a blank. Thermal denaturation was monitored at $260 \mathrm{~nm}$ on a Varian Cary 100 Bio UV-Visible Spectrophotometer, temperature was incremented at $0.1^{\circ} \mathrm{C} / \mathrm{min}$.

AFM imaging. A $5 \mu \mathrm{L}$ sample drop was spotted on freshly cleaved mica (Ted Pella, Inc.) and left to adsorb to the surface for $2 \mathrm{~min}$. To remove buffer salts, 5-10 drops of doubly distilled water were placed on the mica, the drops were shaken off, and the sample was dried with compressed air. Imaging was performed under 2-propanol in a fluid cell on a NanoScope IIIa, using NP-S oxidesharpened silicon nitride probe (Veeco Probes). 


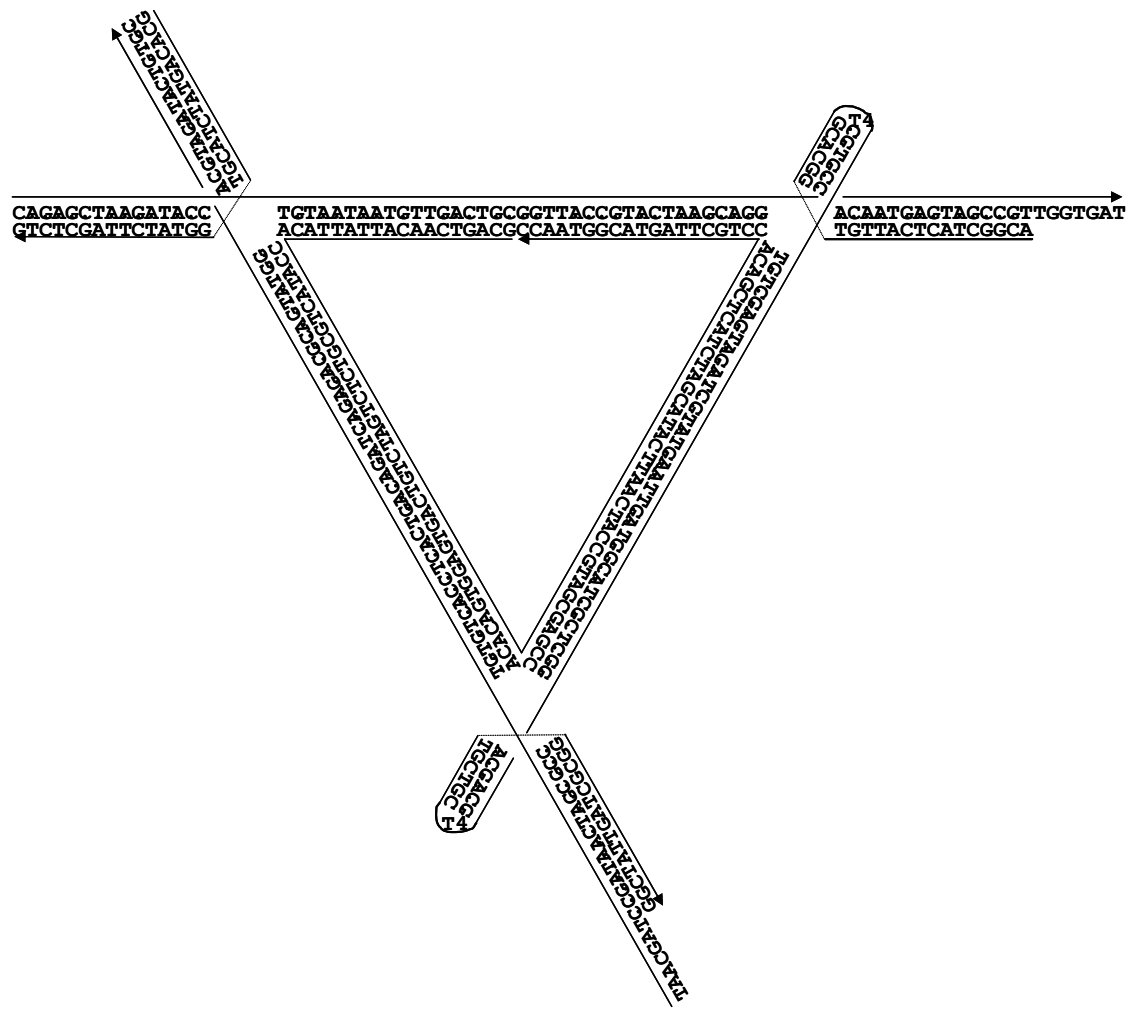

Figure S1. DNA sequence for individual triangle.

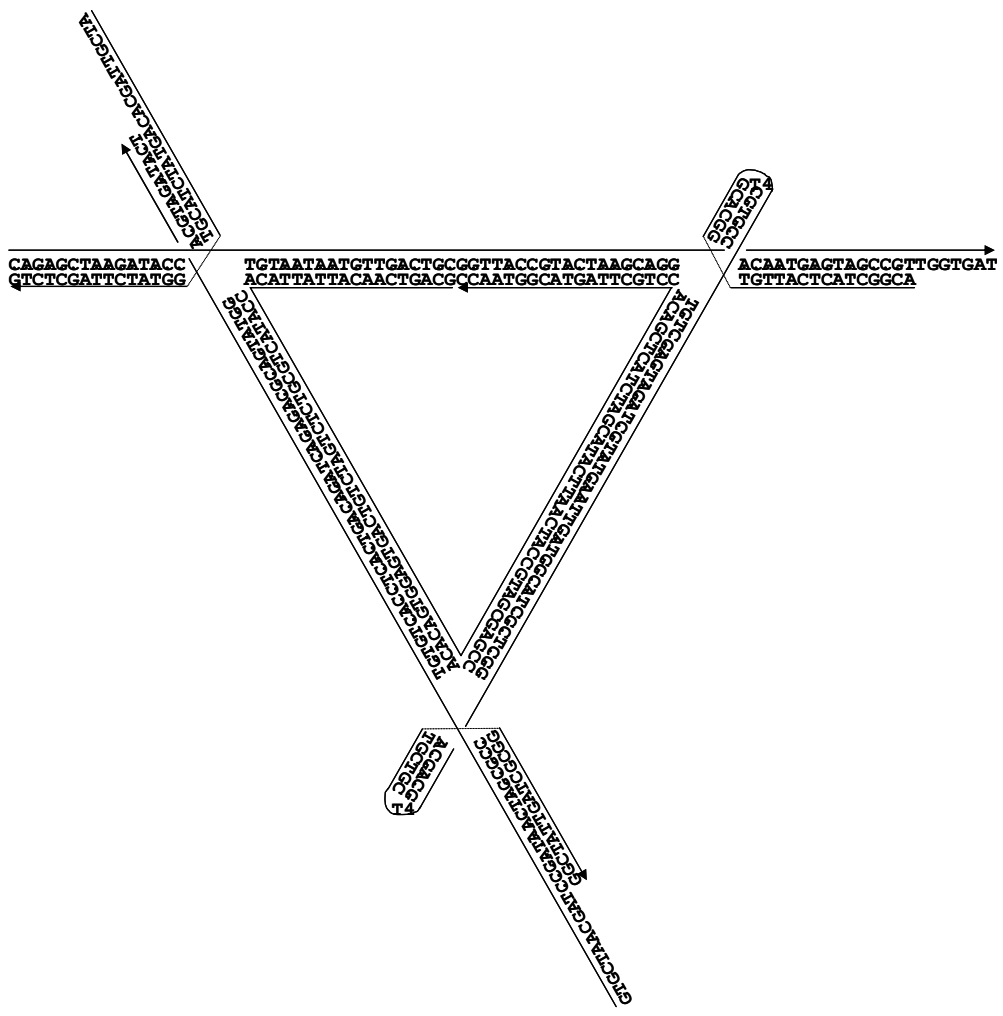

Figure S2. DNA sequence for the 1D triangle array with perodicity of 7 turns of DNA duplex. 


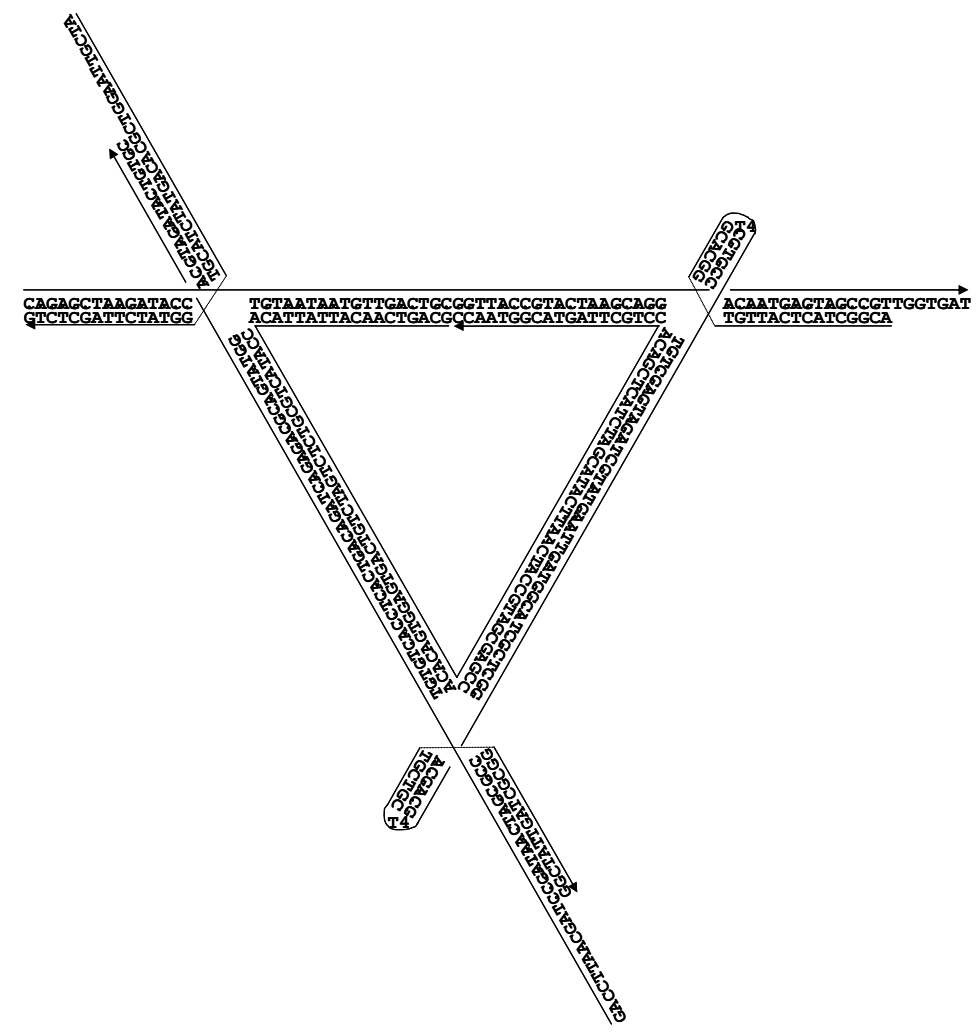

Figure S3. DNA sequence for the 1D triangle array with perodicity of 7.5 turns of DNA duplex.

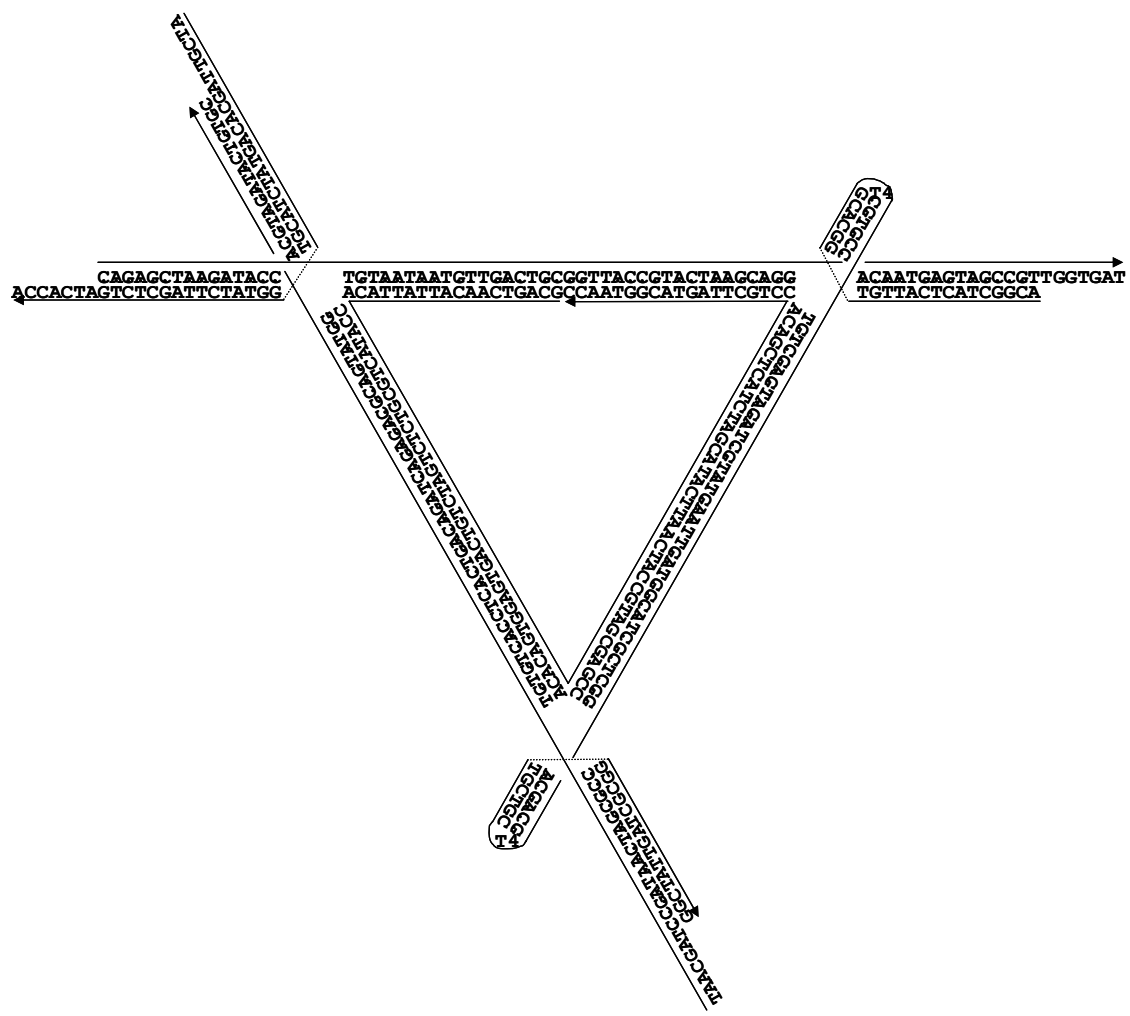

Figure S4. DNA sequence for $2 \mathrm{D}$ triangle array. 

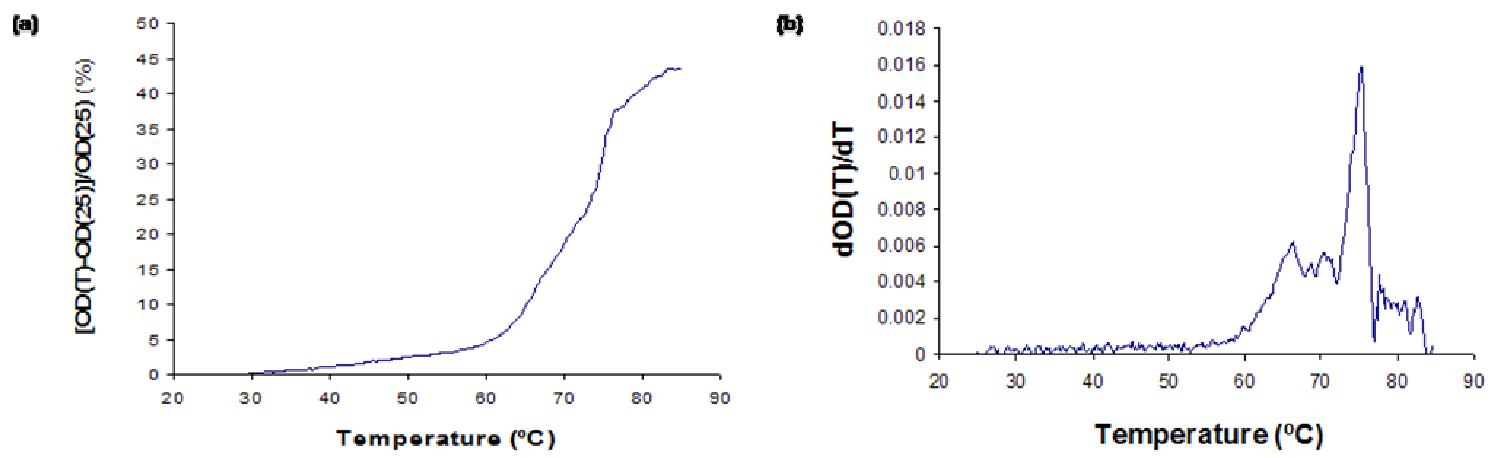

Figure S5. Thermal denaturation of DNA triangles. (a) The relative change of optical density at 260 $\mathrm{nm}$ as a function of temperature. (b) The differential melting behavior of the triangle. Both pictures evidenced that the DNA triangle has multiple transitions. This is expected for this triangle construct, since it contains many helical domains with different lengths. A longer helical damain will be more stable and melt at a higher temperature than a shorter helical domain. Similar phenomenon has been reported before. ${ }^{7 \mathrm{~b}}$

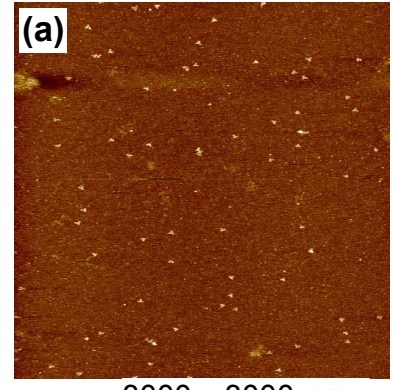

$3000 \times 3000 \mathrm{~nm}$

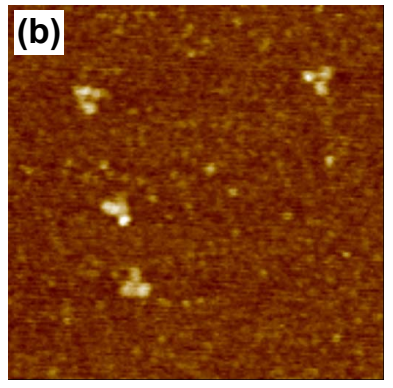

$500 \times 500 \mathrm{~nm}$

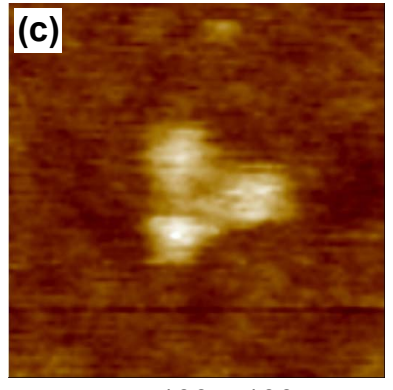

$100 \times 100 \mathrm{~nm}$

Figure S6. AFM images of individual triangles with three different scanning sizes. Please note that the trianlge is not planar (Fig 1a) in solution. When samples were deposited onto mica surface, all duplexes adhered to mica electrostatically and became planar. However, DNA duplexes laid on each other at three vortexes of a triangle and could not compress. So the images were higher at the three vortexes. 

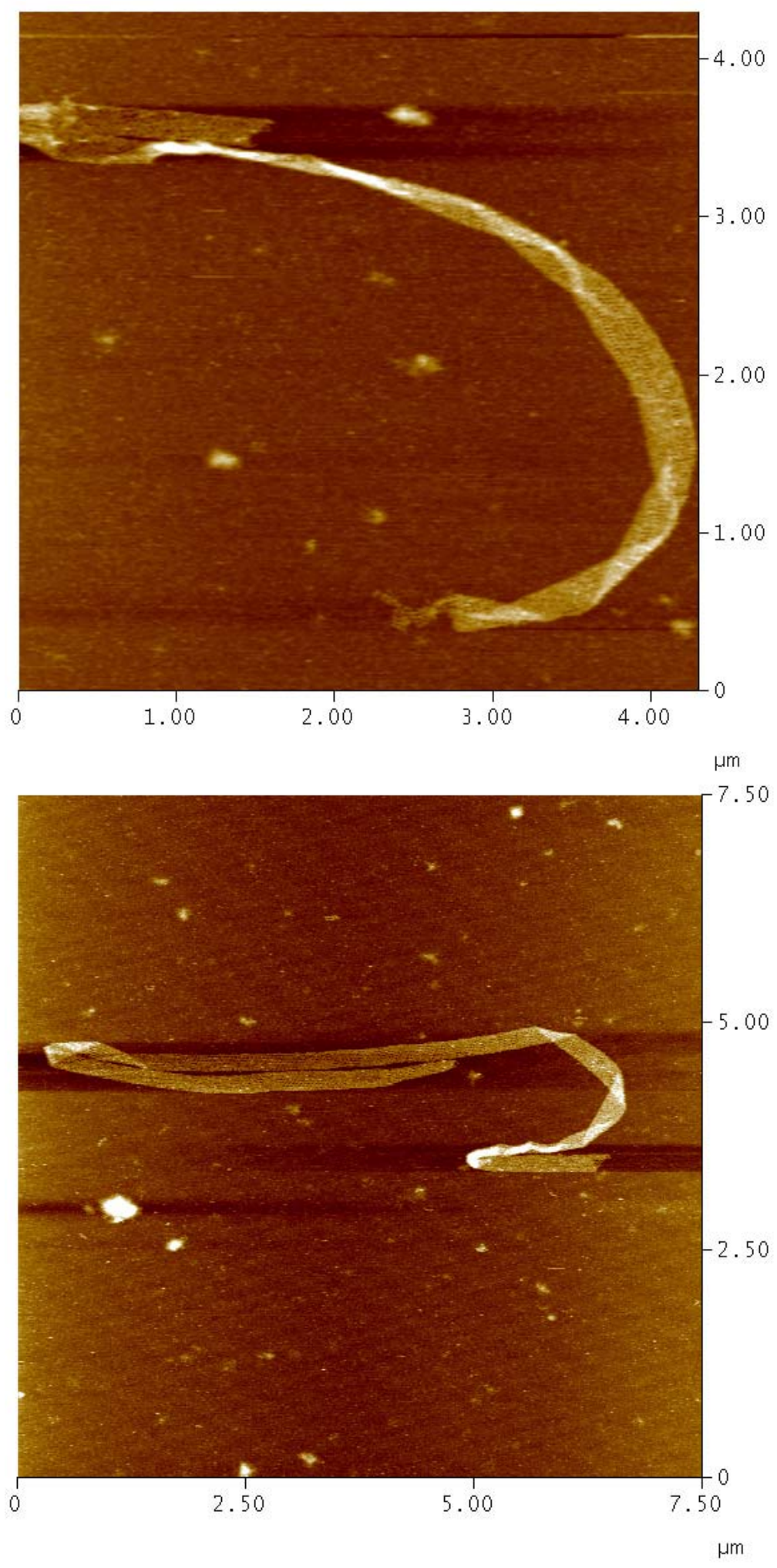

Figure S7. AFM images of large 2D triangle arrays. 